\title{
Pharmacognostical Study of the Fruit Peels of Punica granatum
}

\author{
Rofidah Yasen Ahmed Diab, Ahlam Salih Eltahir* \\ Botany Department, Faculty of Science and Technology, Omdurman Islamic University, Omdurman, Sudan \\ Email: *ahlam.eltahir@yahoo.com
}

How to cite this paper: Diab, R.Y.A. and Eltahir, A.S. (2019) Pharmacognostical Study of the Fruit Peels of Punica granatum. Open Access Library Journal, 6: e5687.

https://doi.org/10.4236/oalib.1105687

Received: August 9, 2019

Accepted: September 23, 2019

Published: September 26, 2019

Copyright $\odot 2019$ by author(s) and Open Access Library Inc.

This work is licensed under the Creative Commons Attribution International License (CC BY 4.0).

http://creativecommons.org/licenses/by/4.0/

\begin{abstract}
This study deals with Punica granatum fruit peels. This plant was selected because of its popularity and being highly used; it was purchased from herbarium markets of Khartoum Sudan. The study is divided into two parts, the main part is a morph-anatomical study of the fruit peels of the plant because it is important in the identification of the medicinal plant when it is in the powder or broken forms. The preparation of permanent slides was done using wax methods. The results of the morph anatomical studies were described and shown in photomicrographs. Transverse section of the peels of the fruits of $P$. granatum is formed of one cell thick epidermis covered by a thin cuticle, followed by many layers of small compact parenchyma cells forming pigment layer and several cell thick isodiametric spongy parenchyma cells filling the section. Vascular bundles are small distributed within the ground parenchyma cells; sclerenchyma cells in the form of stone cells were densely distributed on the section of the peel of fruit. Part two includes physiochemical studies of the powder of the fruit peel to determine the percentage values of moisture, ash, acid insoluble ash, alcohol soluble extractives, and water soluble ash.
\end{abstract}

\section{Subject Areas}

Subject Areas Plant Science

\section{Keywords}

Punica granatum, Lythraceae, Fruit Peels, Morphology Anatomy

\section{Introduction}

Punica. granatum (pomegranates), is a fruit-bearing deciduous shrub or small tree in the family Lythraceae that grows between 5 and $8 \mathrm{~m}$ tall. The fruit contains many seeds separated by white, membranous pericarp. Each seed is sur- 
rounded by tart and red juice. Pomegranates are used in baking, cooking, juice blends, meal garnishes, smoothies, and alcoholic beverages, such as cocktails and wine [1]. The Pgranatum has many spiny branches with lance shaped glossy leaves. The bark of the tree turns gray as the tree ages. The flowers are large, red, white, or variegated having a tubular calyx. The ripe fruit is about five inches wide with a deep red, leathery skin, grenade shaped with a pointed calyx. The fruit contains many seeds separated by white, membranous pericarp. Each seed is surrounded by tart and red juice.

Pomegranate is considered "A pharmacy unto itself" [2]. Pomegranate has many potential effects including bactericidal, antifungal, antiviral, immune modulation, vermifuge, and stimulant, refrigerant, astringent, stomachic, styptic, laxative, diuretic and anti-helminthic. It has also been widely used in treatment of cardiovascular diseases, diabetes, diarrhea, dysentery, asthma, bronchitis, cough, bleeding disorders, fever, inflammation, acquired immune deficiency syndrome, dyspepsia, ulcers, bruises, sores, mouth lesions, skin lesions, malaria, prostate cancer, atherosclerosis, hypertension, hyper lipidemia, denture stomatitis, male infertility, vaginitis, erectile dysfunction, Alzheimer's disease, obesity, and neonatal hypoxic-ischemic brain injury [3] [4].

Microscopy of the fruit peels of Pgranatum was described [5] as having a cuticle layer on the outer surface (pericarps) followed by epidermal cells, lenticels evenly distributed on the epidermis. Protective sclerenchyma cells were densely distributed on the peel of fruit. Vascular bundles and sclerenchyma cells were located between parenchyma cells.

This study aimed to supply some of the diagnostic characters for correct and valid identification of raw materials of $P$. granatum fruit peels and to avoid adulteration and to certify their raw material for quality control.

\section{Materials and Methods}

\subsection{Plant Materials}

Fruits peels from P. granatum family Lytheraceae were selected for this study, they were purchased from local markets from Khartoum, central Sudan. They were identified and authenticated.

\subsection{Morphology}

The external features of the fruit peel of $P$. granatum were documented. The morphological studies were carried out for color, surface, shape, taste size, and odor.

\subsection{Anatomy}

The anatomical investigation was achieved through transverse sections of the plant by a hand microtome using wax method [6]. The fruit peel parts were fixed in a fixative of (F. A. A.) Formaldehyde: Acetic acid: Alcohol (5:5:90 v/v) for 24 hours, washed with distilled water, dehydrated by using serial concentrations of ethyl alcohol 70\%, 90\%, 95\% and absolute alcohol respectively, cleared and lo- 
cated in wax to give the desired section, after that the plant segments were sectioned using a Rotatory Microtome (Leitz1512 West Germany) adjusted at $7 \mathrm{mi}-$ crons. Using a brush, the ribbons of sections were collected on glassed slides, which had been wetted with egg albumin to keep the sections attached to the slides mounted in a drop of D.P.X. and was covered with a cover slip. The prepared slides were left to dry in an oven adjusted at $60^{\circ} \mathrm{C}$ for at least three days. The prepared permanent slides were examined using (Leitz Dialux20) Microscope with large field of view, using power $\times 40$ and $\times 100$ and were photographed using a Samsung Galaxy note 5 phone.

\subsection{Physiochemical Methods}

Moisture contents, ash contents: total ash and acid insoluble ash, water soluble Ash and alcohol soluble extractive were determined [7].

\section{Results and Discussion}

\subsection{Morphology}

\section{Punica granatum fruit peels}

Figure 1 shows the morphological features of Punica granatum fruit.

Origin: Peels of ripe fruit

Color: Red leathery skin the interior membranous walls and white spongy

Surface: Hard and coriaceous

Shape: Grenade

Taste: Astringent

Odor: Little

Dimensions: Thickness of the peel around 2.5 to $3.0 \mathrm{~mm}$

\subsection{Anatomy}

Transverse section of the peels of the fruits of $P$. granatum as shown in Figure 2 is formed of epidermis which is the outer most cell layer formed of one cell thick of small cells covered by a thin cuticle layer on the outer surface. The epidermis is followed by many layers of small compact parenchyma cells forming pigment layer. Below pigment layer are several cell thick isodiametric spongy parenchyma cells filling the section. Vascular bundles are small and are distributed within

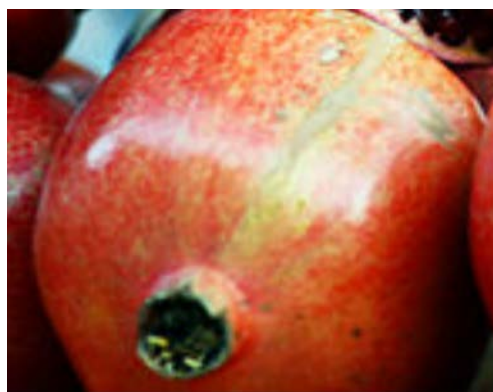

(a)

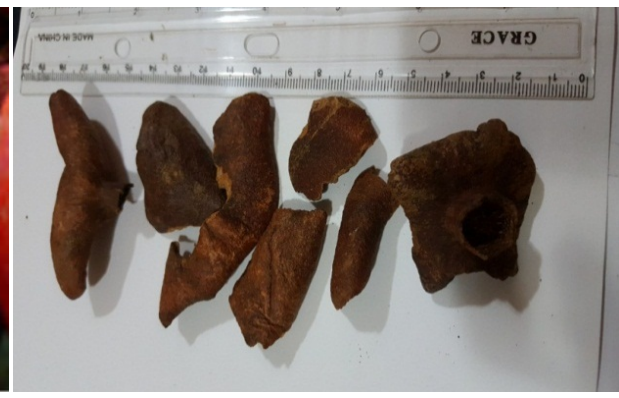

(b)

Figure 1. Punica granatum (a) fruit (b) fruit peels. 


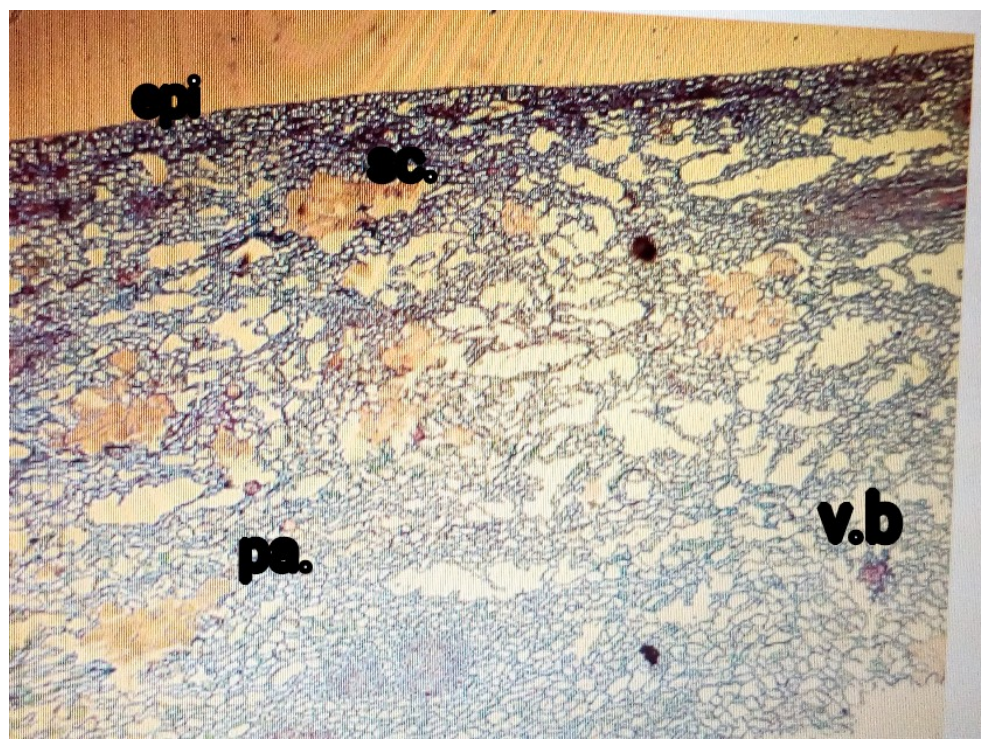

Figure 2. Transverse section of the fruit peel of $P$. granatum $(\times 100)$. epi.: epidermis, pa.: parenchyma, sc.: sclerenchyma, v.b.: vascular bundle.

the ground parenchyma cells. It was found that protective sclerenchyma cells in the form of stone cells were densely distributed on the section of the peel of fruit. The fruit peel were studied [8] the epidermis has shown evenly distributed lenticels which function as stomata and were characterized as extending from loosely lined complementary cell surface. They also studied the powder which shows isolated or groups of stone cells, cluster and prismatic crystals of calcium oxalate and starch grains.

\subsection{Physiochemical Analysis}

Physiochemical are of great values for characterization of the plant drugs. Their values may not be constant since they may change with different factors like the climatic conditions, the type of the soil and the age of the plant when collected [9]. The fruit peels of $P$. granatum were studied for the percentages of moisture contents, ash contents including total ash, acid insoluble ash, water soluble ash and alcohol soluble extractives. Table 1 demonstrates the results of physicochemical analysis. The percentages were calculated with reference to the dry weight of the plant. These values are the means of triplicate readings. The moisture content had a rate of below $10 \%$ this water content rate, prevent oxidation reactions, fermentation and give less chance to microbial growth and contamination in drugs [10]. This result complies with the standards established by the International Pharmacopoeia. Ash values indicate presence of various impurities like carbonate, oxalate and silicate. The water soluble ash is used to estimate the amount of inorganic compound present in drugs. The acid insoluble ash consist mainly silica and indicate contamination with earthy material. Estimation of extractive values determines the amount of the active constituents in a given amount of plant material when extracted with a particular solvent. 
Table 1. Physiochemical analysis results.

\begin{tabular}{cc}
\hline Moisture\% & $8.5002 \pm 0.0546$ \\
Ash\% & $4.5013 \pm 0.4093$ \\
Water Soluble ash\% & $0.1421 \pm 0.0003$ \\
Acid Insoluble Ash\% & $0.5617 \pm 0.0027$ \\
Alcohol Soluble Extractive\% & $43.8386 \pm 13.4909$ \\
\hline
\end{tabular}

\section{Conclusion}

This study is important and lays down parameters for good quality control and authentication of the studied plants with the help of which adulteration and substitution can be proved. The transverse section of Punica granatum fruit peels showed pigment layer of several cell thick isodiametric spongy parenchyma cells filling the section. Vascular bundles are small and are distributed within the ground parenchyma cells. It was found that protective sclerenchyma cells in the form of stone cells were densely distributed on the section of the peel of fruit.

\section{Recommendations}

Anatomical powder studies and comparisons with adulterants of these plants can be conducted to reach a complete monograph and lay down the diagnostic features for fulfillment of right identification.

\section{Acknowledgements}

Thanks to Mr. Kamil Eljack for preparing the slides.

\section{Conflicts of Interest}

The authors declare no conflicts of interest regarding the publication of this paper.

\section{References}

[1] Salgado, A.D., Maia, J.L., Pereira, S.L., de Lemos, T.L. and Mota, O.M. (2006) Antiplaque and Antigingivitis Effects of a Gel Containing Punica granatum Linn Extract. A Double-Blind Clinical Study in Humans. Journal of Applied Oral Science, 14, 162-166. https://doi.org/10.1590/S1678-77572006000300003

[2] Jurenka, J.S. (2008) Therapeutic Applications of Pomegranate (Punica granatum L.): A Review. Alternative Medicine Review, 13, 128-144.

[3] Prakash, C.V.S. and Prakash, I. (2011) Bioactive Chemical Constituents from Pomegranate (Punica granatum) Juice, Seed and Peel-A Review. International Journal of Research in Chemistry and Environment, 1, 1-18.

[4] Miguel, M.G., Neves, M.A. and Antunes, M.D. (2010) Pomegranate (Punica granatum L.): A Medicinal Plant with Myriad Biologic Properties: A Short Review. Journal of Medicinal Plants Research, 4, 2836-2847.

[5] Yazıc1, K., Kaynak, L. and Cevik, M.S. (2009) Anatomy of Pomegranate (Punica granatum L. "Hicaznar") Fruit Exocarp. Pomegranate and Minor, Including Medi- 
terranean Fruits, Dharwad, 23-27 June 2009, 215-220.

[6] Willy, R.L. (1971) Micro-Techniques: A Laboratory Guide. The Macmillan Company, New York.

[7] AOAC (1990) Association of Analytical Chemistry. Volume 1, 5th Edition.

[8] Ambili, D.S., Padyana, S., Mahesh and Sree, R. (2017) Punica Granatum: Study on Its Pharmacognostical and Phytochemical Properties. International Journal of Ayurvedic and Herbal Medicine, 7, 2886-28915.

[9] WHO (1990) Monographs on Selected Medicinal Plants. Vol. I, World Health Organization, Geneva.

[10] Organisation de l'unitéafricaine/commission scientifique technique et de la recherche (OUA/CSTR) (1998) Pharmacopéeafricaine, méthodesgénéralesd' analyses. Edn 1, Publisher, Lagos, 254. 